\title{
Penentuan Waktu Panen Pisang Raja Bulu Berdasarkan Evaluasi Buah Beberapa Umur Petik
}

\author{
Determination of Harvest Time of Raja Bulu Banana Based on Postharvet \\ Evaluation of Fruit at Different Picking Time
}

Mustika Dwi Rahayu', Winarso Drajad Widodo ${ }^{2 *}$, dan Ketty Suketi ${ }^{2}$

Diterima 2 Juli 2014/Disetujui 15 Agustus 2014

\begin{abstract}
Bananas are commonly consumed because of their nutrition content and affordability. Banana fruits are rapidly over riped. Therefore, harvest time is key point for long shelf life. The aims of this study is to analyze the criteria of Raja Bulu Banana's (Musa paradisiaca) ripeness in post-harvest with several picking dates and to determine the best picking date for favorable post harvest handling. This study was conducted from January until June 2014. Tagging was held in January at farmer located in Sumedang (900 $\mathrm{m}$ above sea level, West Java). The post-harverst evaluation was conducted from Mei until June at the Postharvest Laboratory, Departement of Agronomy and Horticulture, Faculty of Agriculture, Bogor Agricultural University. The experiment was arranged in a randomized complete block design using single factor with 5 replications for 5 picking dates, i.e. 85, 90, 95, 100, 105 and 3 replications for 110 days after anthesis (DAA). This study showed that the best picking-time for Raja Bulu Banana was achieved in 85 DAA with 11 days of shelf-life and heat units $1305.5^{\circ} \mathrm{C}$ day. The later the picking age was negatively correlated with the length of shelf life. The younger the picking age was negatively correlated with respiration rate. Picking date did not affect the physical and chemical quality of post-harvest fruit at the same maturity level.
\end{abstract}

Keywords: color scale, respiration rate, shelf life

\begin{abstract}
ABSTRAK
Pisang lebih disukai oleh masyarakat karena harganya yang terjangkau dan banyak mengandung vitamin dan mineral. Buah pisang memiliki permasalahan pascapanen buah karena yang cepat masak. Tujuan penelitian ini adalah mempelajari kriteria kematangan pascapanen buah pisang Raja Bulu dari beberapa umur petik dan menentukan saat panen terbaik untuk penanganan pascapanen. Percobaan dilaksanakan pada bulan Januari sampai Juni 2014. Penandaan bunga pisang dilaksanakan pada bulan Januari di kebun pisang milik warga di Sumedang Jawa Barat pada ketinggian $900 \mathrm{~m}$ dpl dan pengujian pascapanen dilaksanakan pada bulan Mei hingga Juni di Laboratorium Pascapanen, Departemen Agronomi dan Hortikultura, Fakultas Pertanian, Institut Pertanian Bogor. Percobaan dilaksanakan dengan rancangan kelompok lengkap teracak (RKLT) faktor tunggal dengan 6 umur petik sebagai perlakuan, yaitu 85, 90, 95, 100, dan 105 hari setelah antesis (HSA) masing-masing dengan 5 ulangan dan 3 ulangan untuk 110 (HSA) sehingga terdapat 28 satuan percobaan. Hasil percobaan menunjukkan bahwa umur petik terbaik pisang Raja Bulu dicapai pada 85 HSA dengan umur simpan terlama (11 hari) serta satuan panas sebesar $1305.5{ }^{\circ} \mathrm{C}$ hari. Buah pisang yang dipetik tua lebih cepat mencapai kematangan pascapanen dibandingkan dengan buah pisang yang dipetik muda. Pisang yang dipetik muda memiliki laju respirasi yang rendah dibandingkan dengan buah pisang yang dipetik tua. Umur petik tidak mempengaruhi mutu fisik dan kimia buah pisang pada tingkat kematangan pascapanen yang sama.
\end{abstract}

Kata kunci: laju respirasi, skala warna, umur simpan

\footnotetext{
${ }^{1}$ Alumni Departemen Agronomi dan Hortikultura, Institut Pertanian Bogor

${ }^{2}$ Staff Pengajar Departemen Agronomi dan Hortikultura, Fakultas Pertanian, Institut Pertanian Bogor,

Telp.\&Faks. 62-251-8629353*e-mail korespondensi: wd_widodo@yahoo.com
} 


\section{PENDAHULUAN}

Pisang merupakan buah yang banyak digemari oleh semua kalangan masyarakat karena harganya yang relatif murah, mudah dibudidayakan dan dapat dipanen sepanjang tahun. Pisang mengandung vitamin, mineral, dan serat, yang dapat dikonsumsi kapan saja dan pada segala tingkatan usia. Menurut data Biro Pusat Statistik (2013) perkembangan produksi nasional buah pisang meningkat dari 5.76 juta ton pada tahun $2010,6.13$ juta ton pada tahun 2011 sampai 6.19 juta ton pada tahun 2012. Data dari Pusat Kajian Hortikultura Tropika (2014) menunjukkan nilai ekspor pisang mengalami kenaikan dari 1.49 juta ton pada tahun 2012 menjadi 2.33 juta ton pada tahun 2013, hal ini membuka peluang usaha untuk menyuplai kebutuhan baik di dalam negeri maupun di luar negeri.

Peluang pengembangan agribisnis pisang sangat terbuka luas diantaranya pengembangan produk olahan pisang seperti manisan pisang, keripik pisang, dan tepung pisang (Cahyono, 2009). Penelitian terbaru dari Hanum et al. (2012) menunjukkan limbah kulit buah pisang dapat dijadikan sebagai sumber pektin. Senyawa pektin banyak digunakan dalam industri farmasi, makanan, dan minuman. Menurut Firdaus et al. (2008) kulit pisang kepok dapat diolah sebagai penghasil asam laktat.

Masalah pascapanen yang terjadi di pasaran yaitu buah pisang yang dijual tidak menarik konsumen akibat adanya luka fisik pada buah, seperti kulit yang kehitaman, terdapat bintik-bintik kecoklatan, tergores dan tekstur yang lembek. Kondisi demikian mengakibatkan nilai jual pisang rendah dan berdampak pada rendahnya pendapatan petani (Suryana, 2006). Buah pisang termasuk bahan pangan yang mudah rusak (perishable) karena masih berlangsungnya proses respirasi meskipun buah tersebut sudah dipanen (Kuntarsih, 2012). Penelitian Sutowijoyo (2013) menyatakan panen terbaik untuk penanganan pascapanen dalam rangka memperpanjang umur simpan pada pisang Raja Bulu adalah 95 HSA sedangkan untuk pisang kepok 110 HSA. Masalah penangananan pascapanen pada pisang salah satunya adalah penentuan umur petik yang kurang tepat. Hal ini berdampak pada mutu dan kualitas pisang akibat terlalu cepat atau terlalu lambatnya petani dalam menentukan umur petik. Mengacu pada permasalahan tersebut maka penelitian ini dilakukan untuk mendapatkan umur petik terbaik untuk penanganan pascapanen selanjutnya. Tujuan penelitian ini adalah mempelajari kriteria kematangan pascapanen buah pisang Raja Bulu dari beberapa umur petik dan menentukan saat panen terbaik untuk penanganan pascapanen.

\section{BAHAN DAN METODE}

Penelitian dilaksanakan pada bulan Januari hingga Juni 2014. Penandaan buah dilaksanakan pada bulan Januari di kebun pisang milik warga di Sumedang Jawa Barat pada ketinggian $900 \mathrm{~m}$ di atas permukaan laut dan pengujian pascapanen dilaksanakan pada bulan Mei hingga Juni di Laboratorium Pascapanen, Departemen Agronomi dan Hortikultura, Fakultas Pertanian, Institut Pertanian Bogor.

Bahan-bahan yang digunakan dalam penelitian ini yaitu pisang Raja Bulu dengan umur petik 85, 90, 95, 100, 105 dan 110 hari setelah antesis (HSA), kain saring, kertas koran bahan aktif Natrium Hipoklorit, larutan phenoptalein, aquades, serta $\mathrm{NaOH} 0.1 \mathrm{~N}$. Alat-alat yang digunakan terdiri atas termometer, penetrometer, refraktometer, timbangan analitik, kosmotektor, wadah plastik, labu takar, buret, dan gelas ukur.

Rancangan percobaan yang digunakan adalah rancangan kelompok lengkap teracak (RKLT) faktor tunggal 6 variasi umur petik pisang. Pisang Raja Bulu yang digunakan yaitu umur petik 85, 90, 95, 100, 105 hari setelah antesis (HSA) masing-masing dengan 5 ulangan dan 3 ulangan untuk 110 HSA sehingga terdapat 28 satuan percobaan. Setiap tandan diambil 2 sampai 3 sisir untuk pengujian fisik dan kimia buah. Data yang diperoleh dianalisis dengan uji $\mathrm{F}$ pada aplikasi SAS versi 9.1 dan perlakuan yang mempengaruhi dianalisis dengan Duncan Multiple Range Test (DMRT) pada taraf 5\%.

Kegiatan penandaan bunga pisang dilakukan pada bulan Januari 2014 di kebun pisang milik warga di Sumedang, Jawa Barat. Penandaan bunga ini dilakukan untuk mendapatkan buah pisang dengan umur petik yang diinginkan. Penandaan dilakukan setiap 5 
hari dengan menandai 5-7 pohon pisang untuk dijadikan faktor umur petik pertama (110 HSA), 5 hari sebelumnya faktor umur petik kedua (105 HSA) dan 5 hari sebelumnya untuk umur petik ketiga sampai umur petik keenam (85 HSA). Selama masa generatif dilakukan pengukuran suhu setiap hari untuk mengetahui heat unit $\left({ }^{0} \mathrm{C}\right.$ hari) pada pisang sampai pisang tersebut dipanen.

Buah pisang Raja Bulu yang telah dipanen disortasi, kemudian dibersihkan dengan larutan disinfektan Natrium Hipoklorit dengan konsentrasi $10 \%$ untuk mengendalikan cendawan yang terdapat pada kulit buah, lalu dikering-anginkan. Buah yang telah selesai dikeringkan diletakkan di atas koran atau kardus di dalam ruangan dengan suhu 25 sampai $30{ }^{\circ} \mathrm{C}$ dengan kelembaban 70 sampai $80 \%$.

Parameter yang diamati meliputi: laju respirasi, karakter fisik, dan karakter kimia. Karakter fisik meliputi indeks skala warna kulit buah, umur simpan, susut bobot buah, bagian buah yang dapat dimakan, dan kelunakan buah. Karakter kimia yang diamati yaitu padatan terlarut total dan asam tertitrasi total. Pengukuran laju respirasi dilakukan setiap hari sampai buah mengalami kebusukan yang ditandai dengan bintik-bintik hitam pada kulit buah. Pengukuran laju respirasi dilakukan dengan mengukur volume udara bebas dalam wadah plastik, bobot pisang, kemudian diinkubasi selama 2 jam. Perubahan warna diamati menggunakan derajat kekuningan kulit buah yang dinilai dengan skala hijau sampai $100 \%$ kuning yang mengacu pada hasil penelitian Sugistiawati (2013), Sutowijoyo (2013) dan Arista (2014). Indeks skala warna kulit buah diamati setiap hari untuk melihat perubahan warna kulit buah yang digunakan sebagai parameter untuk pengukuran umur simpan, susut bobot, bagian buah yang dapat dimakan, kelunakan buah, padatan terlarut total dan asam tertitrasi total.

\section{HASIL DAN PEMBAHASAN}

\section{Umur Simpan Buah}

Umur simpan merupakan parameter utama untuk mengetahui daya simpan buah pisang dalam mempertahankan kesegarannya sampai buah tersebut ketangan konsumen. Umur simpan diamati dari perubahan skala warna kulit buah pisang dimulai dari skala warna $1,2,3,4,5,6$ sampai skala warna 7 . Hasil penelitian menunjukkan bahwa semakin tua umur petik, semakin cepat mencapai kematangan pascapanen sehingga masa simpannya menjadi lebih pendek. Umur simpan pisang Raja Bulu pada beberapa tingkat kematangan disajikan pada Tabel 1.

Umur petik tidak mempengaruhi umur simpan pisang Raja Bulu pada skala warna 1 sampai 3 hal ini disebabkan karena laju respirasi yang masih rendah sehingga pemasakan buah lambat ketika buah masih hijau. Umur petik mempengaruhi umur simpan pisang skala warna 4 sampai 7 pada skala tersebut umur petik yang lebih tua mempunyai umur simpan yang lebih rendah dibandingkan dengan umur petik yang masih muda. Umur petik 110 HSA tidak dilakukan pengamatan pada skala warna 1 sampai 4 disebabkan pada waktu dipetik, buah telah kuning penuh akibat masa panen yang terlalu lama sehingga pengamatan hanya dapat dimulai pada skala warna 5.

Tabel 1. Lama Simpan Saat Skala kulit buah pisang Raja Bulu Tercapai

\begin{tabular}{cccccccc}
\hline \multirow{2}{*}{ Umur petik } & \multicolumn{7}{c}{ Umur simpan (hari $)^{\mathrm{a}}$} \\
\cline { 2 - 8 } & Skala 1 & Skala 2 & Skala 3 & Skala 4 & Skala 5 & Skala 6 & Skala 7 \\
\hline 85 HSA & 3.0 & 4.0 & 5.0 & $7.4 \mathrm{a}$ & $9.2 \mathrm{a}$ & $10.8 \mathrm{a}$ & $11.8 \mathrm{a}$ \\
$90 \mathrm{HSA}$ & 3.0 & 4.0 & 4.0 & $4.4 \mathrm{~b}$ & $5.2 \mathrm{bc}$ & $6.4 \mathrm{~b}$ & $7.6 \mathrm{bc}$ \\
$95 \mathrm{HSA}$ & 3.0 & 4.0 & 4.2 & $4.6 \mathrm{~b}$ & $5.6 \mathrm{~b}$ & $5.8 \mathrm{~b}$ & $8.6 \mathrm{ab}$ \\
$100 \mathrm{HSA}$ & 3.0 & 4.0 & 4.2 & $4.6 \mathrm{~b}$ & $5.8 \mathrm{~b}$ & $6.2 \mathrm{~b}$ & $8.4 \mathrm{ab}$ \\
$105 \mathrm{HSA}$ & 3.0 & 4.0 & 4.2 & $5.0 \mathrm{~b}$ & $5.2 \mathrm{bc}$ & $6.6 \mathrm{~b}$ & $7.6 \mathrm{bc}$ \\
110 HSA $^{\text {b }}$ & - & - & - & - & $3.0 \mathrm{c}$ & $4.0 \mathrm{~b}$ & $4.0 \mathrm{c}$ \\
\hline
\end{tabular}

Keterangan: ${ }^{a}$ Angka-angka pada kolom yang sama yang diikuti huruf yang sama tidak berbeda nyata pada DMRT taraf $5 \%,{ }^{\mathrm{b}}$ Diamati pada buah yang masih dapat dianalisis, HSA = Hari setelah antesis. 
Skala warna 6 digunakan sebagai parameter layak konsumsi dan menjadi tolak ukur untuk pengamatan fisik dan kimia buah. Pada skala warna 6 umur simpan paling lama terdapat pada umur petik 85 HSA yaitu 11 hari masa simpan dan umur simpan paling pendek terdapat pada umur petik 110 HSA dengan lama masa simpan 4 hari (Tabel 1). Sutowijoyo (2013) menyatakan semakin tua umur petik maka daya simpannya menjadi lebih pendek dan sebaliknya.

\section{Laju Respirasi Buah}

Respirasi merupakan proses utama dan penting yang terjadi pada hampir semua makhluk hidup, seperti halnya pada buah. Pada buah klimaterik disamping terjadi kenaikan respirasi juga terjadi kenaikan kadar etilen selama proses pematangan. Laju respirasi dipengaruhi beberapa faktor seperti suhu, umur petik dan kondisi fisik buah. Laju respirasi pisang Raja Bulu pada beberapa umur petik dapat dilihat pada Tabel 2 .

Variasi umur petik berpengaruh terhadap laju respirasi. Laju respirasi terendah terdapat pada umur petik 85 HSA sebesar $829.1 \mathrm{mg} \mathrm{CO} / \mathrm{kg} / \mathrm{jam}$ dan tertinggi terdapat pada umur petik 110 HSA sebesar $1959.3 \mathrm{mg}$ $\mathrm{CO}_{2} / \mathrm{kg} / \mathrm{jam}$. Satuan panas terendah terdapat pada umur petik $85 \mathrm{HSA}$ yaitu $1305.5^{\circ} \mathrm{C}$ hari dan tertinggi terdapat pada umur petik 110 HSA yaitu $1674.5{ }^{\circ} \mathrm{C}$ hari. Pisang Raja Bulu dapat dipetik pada 85 HSA dengan lama simpan 11 hari dan satuan panas $1305.5{ }^{\circ} \mathrm{C}$ hari. Hasil penelitian Sumantra et al. (2014) satuan panas pada salak yang ditanam di Tabanan Bali sebesar $1635.12{ }^{\circ} \mathrm{C}$ hari.

Tabel 2. Laju respirasi dan jumlah suhu harian rata-rata pisang Raja Bulu

\begin{tabular}{ccc}
\hline Umur petik & $\begin{array}{c}\text { Laju respirasi } \\
(\mathrm{mg} \\
\left.\mathrm{CO}_{2} / \mathrm{kg} / \mathrm{jam}\right)^{\mathrm{a}}\end{array}$ & $\begin{array}{c}\text { Satuan panas } \\
\left({ }^{0} \mathrm{C} \text { hari }\right)\end{array}$ \\
\hline $85 \mathrm{HSA}$ & $829.1 \mathrm{c}$ & 1305.5 \\
$90 \mathrm{HSA}$ & $1434.4 \mathrm{~b}$ & 1383.5 \\
$95 \mathrm{HSA}$ & $1221.3 \mathrm{bc}$ & 1459.0 \\
$100 \mathrm{HSA}$ & $1191.5 \mathrm{bc}$ & 1530.0 \\
$105 \mathrm{HSA}$ & $1367.3 \mathrm{bc}$ & 1601.5 \\
$110 \mathrm{HSA}$ & $1959.3 \mathrm{a}$ & 1674.5 \\
\hline Keterangan: ${ }^{a}$ Angka-angka pada kolom yang sama \\
\multicolumn{3}{c}{ yang diikuti huruf yang sama tidak } \\
berbeda nyata pada DMRT taraf 5\%, \\
HSA = Hari setelah antesis
\end{tabular}

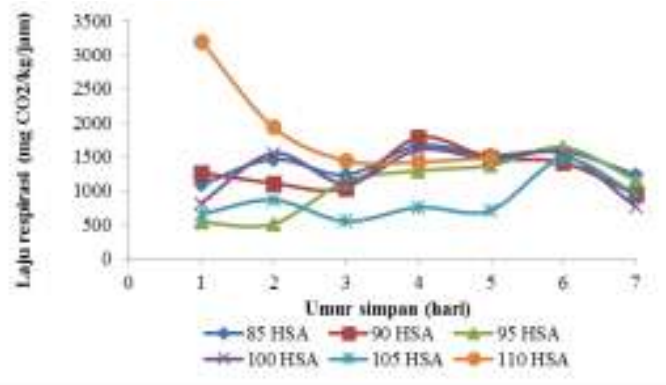

Gambar 1. Pola klimakterik pisang Raja Bulu pada beberapa stadia kematangan

Puncak klimakterik umur petik 85,90 , 95, 100 dan 105 hari yaitu pada 6, 6, 6, 4, 4 hari masa simpan. Puncak klimakterik tertinggi terlihat pada umur petik $110 \mathrm{HSA}$ pada umur simpan satu hari hal ini disebabkan umur panen yang terlalu lama sehingga pada waktu dipetik buah telah matang penuh dan laju respirasi telah mencapai klimakterik serta jumlah satuan panas (heat unit) yang besar (Tabel 2). Pengamatan laju respirasi pada semua perlakuan terjadi penurunan puncak klimakterik secara bersamaan pada 7 hari masa simpan hal tersebut disebabkan buah mulai mengalami kebusukan sehingga kandungan $\mathrm{CO}_{2}$ yang dikeluarkan tidak murni dari pisang melainkan dari cendawan dan penyakit yang menempel pada pisang tersebut. Penyakit yang menyerang pisang selama masa simpan yaitu crown end root dan antraknosa.

Puncak klimakterik pisang ditandai oleh adanya kematangan secara fisiologi dan morfologi (Arista, 2014). Menurut Phan et al. (1986) laju respirasi merupakan petunjuk yang baik bagi daya simpan buah setelah panen karena intensitas respirasi dianggap sebagai ukuran laju jalannya metabolisme dan sering dianggap sebagai petunjuk potensi daya simpan buah. Terdapat beberapa faktor yang mempengaruhi laju respirasi, diantaranya suhu dan faktor fisik pada pisang tersebut seperti luka goresan, memar dan kondisi buah pisang yang sudah mulai membusuk. Hasil penelitian Paramita (2010) menunjukkan bahwa memar berpengaruh terhadap perubahan pola respirasi dan produksi etilen buah mangga (Mangifera indica L.) varietas Gedong Gincu selama penyimpanan. Buah mangga yang mengalami memar akan mengakibatkan pola respirasi dan produksi etilen meningkat. Menurut Sumantra et al. (2014) satuan panas berkorelasi positif dengan proses pematangan buah salak, 
sehingga buah yang mempunyai satuan panas tinggi akan mengalami pemanenan yang lebih cepat dari buah yang mempunyai satuan panas rendah.

Arista (2014) dan Sutowijoyo (2013) melaporkan penyakit crown end root dan antraknosa muncul pada 6 sampai 7 hari masa simpan. Menurut Cahyono (2009) penyakit antraknosa disebabkan oleh cendawan Colletotrichum musae. Infeksi cendawan tersebut akan mempercepat kerusakan buah ketika sudah matang dalam penyimpanan sehingga buah menjadi cepat membusuk.

\section{Kualitas Fisik Buah}

Indeks skala warna kulit buah digunakan sebagai parameter dalam mengukur kualitas fisik buah dengan mengamati pisang secara visual. Pisang yang telah mencapai indeks skala warna 6 ditentukan sebagai kriteria layak konsumsi. Hasil pengukuran kelunakan buah, susut bobot dan bagian buah yang dapat dimakan pada skala warna 6 disajikan pada Tabel 3.

Umur petik tidak mempengaruhi kelunakan dan bagian buah yang dapat dimakan. Umur petik 85 HSA sampai 105 HSA memiliki nilai yang tidak berbeda pada susut bobot buah. Umur petik hanya mempengaruhi susut bobot pada 110 HSA karena buah telah mencapai skala warna 5 dan tidak dapat dilakukan pengukuran bobot awal pada saat buah masih berwarna hijau sehingga susut bobotnya menjadi lebih rendah dari umur petik yang lain. Kelunakan buah berhubungan dengan umur simpan, semakin lama umur simpan maka semakin lunak buah tersebut. Susut bobot buah mengalami kenaikan selama penyimpanan buah sampai buah tersebut matang. Bagian yang dapat dimakan mengalami kenaikan seiring dengan perubahan skala warna kulit pada buah pisang (Gambar 2).

Perubahan tekstur atau kelunakan pada saat pematangan dihubungkan dengan beberapa proses. Pertama proses penguraian pati menjadi gula, kedua pemecahan dinding sel yang diakibatkan perombakan protopektin yang larut dalam air dan terakhir adalah perombakan selulosa. Perubahan senyawasenyawa tersebut selama pematangan sangat berpengaruh terhadap kekerasan buah, yang menyebabkan buah menjadi lunak (Pantastico,
1986). Buah yang disimpan pada kondisi atmosfer terkendali dengan kombinasi udara 4$\begin{array}{llllll}6 \% & \mathrm{O}_{2} & \text { dan } & 2-4 \% & \mathrm{CO}_{2} & \text { memberikan nilai }\end{array}$ aroma, rasa, warna, dan penerimaan umum yang lebih baik (Julianti et al., 2013)

Proses transpirasi menyebabkan kadar air pada kulit buah lebih cepat berkurang sehingga mengakibatkan semakin turunnya bobot kulit buah pisang (Jannah, 2008). Menurut Sutowijoyo (2013) dan Sugistiawati (2013) semakin matang buah pisang, rasio daging dan kulitnya semakin tinggi, karena kulit buah semakin tua semakin tipis dan mengkerut. Menurut Pantastico (1986) kandungan gula dalam daging buah selama pematangan meningkat dengan cepat sehingga tekanan osmotik meningkat dengan ditandai penyerapan air dari kulit buah oleh daging buah, menyebabkan perubahan perbandingan daging buah dan kulitnya.

Tabel 3. Kualitas fisik pisang Raja Bulu pada skala warna 6

\begin{tabular}{|c|c|c|c|}
\hline $\begin{array}{l}\text { Umur } \\
\text { petik }\end{array}$ & $\begin{array}{l}\left(\mathrm{mm} \cdot \mathrm{g}^{-1} \text {. }\right. \\
\left.\operatorname{detik}^{-1}\right)\end{array}$ & $\begin{array}{c}\text { Susut } \\
\text { bobot } \\
(\%)^{\mathrm{a}}\end{array}$ & $\begin{array}{c}\text { buah } \\
\text { yang } \\
\text { dapat } \\
\text { dimakan } \\
(\%)\end{array}$ \\
\hline 85 HSA & 0.12 & $18.31 \mathrm{a}$ & 61.19 \\
\hline 90 HSA & 0.10 & $18.25 \mathrm{a}$ & 56.02 \\
\hline 95 HSA & 0.09 & $18.53 \mathrm{a}$ & 55.17 \\
\hline 100 HSA & 0.08 & $18.42 \mathrm{a}$ & 62.82 \\
\hline 105 HSA & 0.08 & $18.28 \mathrm{a}$ & 60.49 \\
\hline 110 HSA & 0.14 & $9.10 \mathrm{~b}$ & 62.23 \\
\hline
\end{tabular}



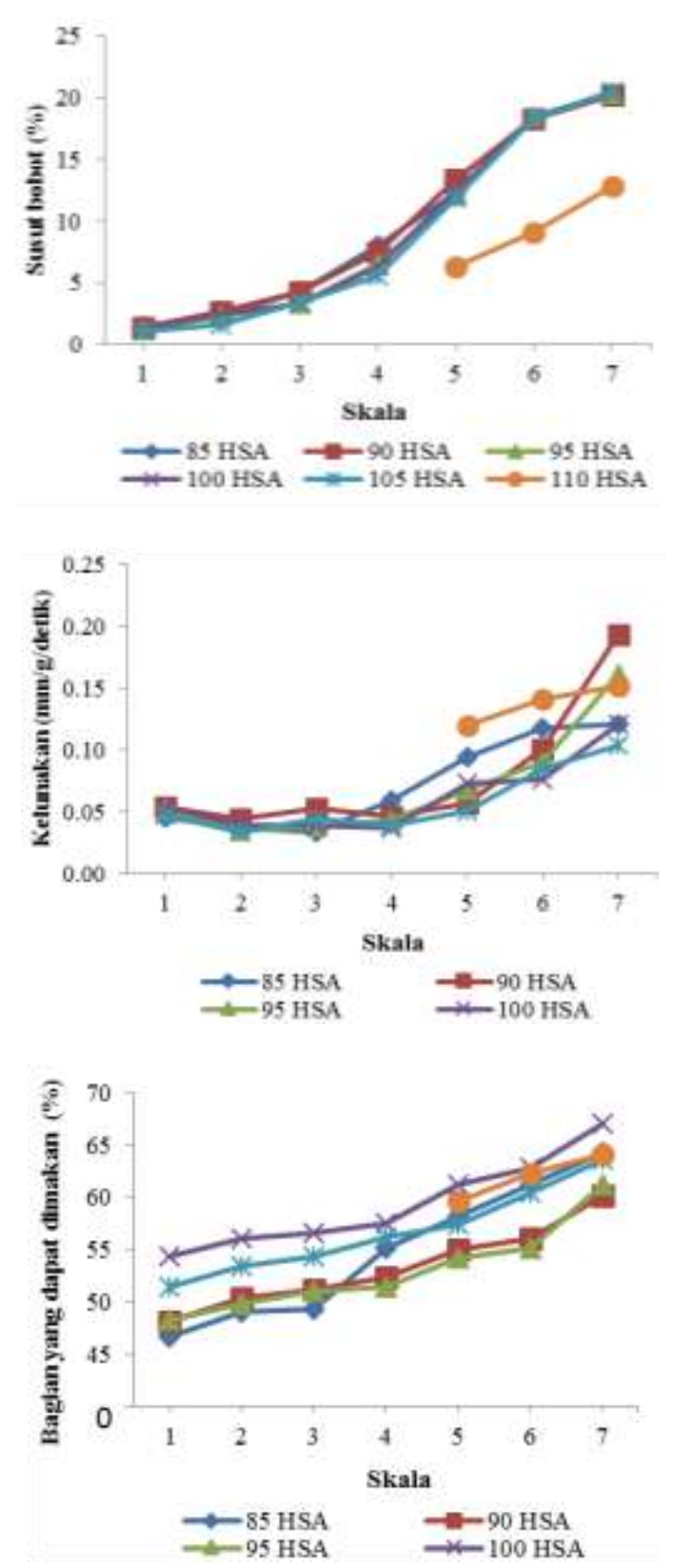

Gambar 2. Kualitas fisik pisang Raja Bulu pada beberapa umur petik

\section{Kualitas Kimia Buah}

Mutu buah berkaitan dengan perubahan komposisi kimia buah yang akan mempengaruhi rasa buah. Kualitas kimia menjadi sangat penting diamati karena merupakan salah satu faktor yang menentukan tingkat penerimaan konsumen. Variasi umur petik tidak mempengaruhi kandungan padatan terlarut total, kandungan asam tertitrasi total dan rasio PTT/ATT.
Tabel 4. Kualitas kimia pisang Raja Bulu pada skala warna 6

\begin{tabular}{cccc}
\hline $\begin{array}{c}\text { Umur } \\
\text { petik }\end{array}$ & $\begin{array}{c}\text { Padatan } \\
\text { terlarut } \\
\text { total } \\
\left({ }^{\circ} \text { Brix }\right)\end{array}$ & $\begin{array}{c}\text { Asam } \\
\text { tertitrasi total } \\
(\mathrm{mg} / 100 \mathrm{~g} \\
\text { bahan })\end{array}$ & $\begin{array}{c}\text { Rasio } \\
\text { PTT/AT } \\
\mathrm{T}\end{array}$ \\
\hline 85 HSA & 29.63 & 27.52 & 1.09 \\
90 HSA & 26.09 & 21.44 & 1.26 \\
95 HSA & 25.72 & 19.52 & 1.34 \\
100 HSA & 27.38 & 21.28 & 1.60 \\
105 HSA & 27.96 & 23.31 & 1.25 \\
110 HSA & 27.33 & 27.20 & 1.02 \\
\hline Keterangan: HSA = Hari setelah antesis, PTT = Padatan \\
\multicolumn{4}{c}{ terlarut total, ATT = Asam tertitrasi total }
\end{tabular}

Warna kulit buah dengan kriteria kematangan yang sama pada umur petik yang berbeda memiliki hasil uji fisik dan kimia yang tidak berbeda (Tabel 3 dan 4), sehingga pisang Raja Bulu sebaiknya dipetik pada umur 85 HSA dengan lama masa simpan 11 hari untuk efisiensi waktu produksi (Tabel 1). Warna kulit buah tidak dapat dijadikan acuan untuk pengamatan kematangan pisang pada umur petik yang berbeda.
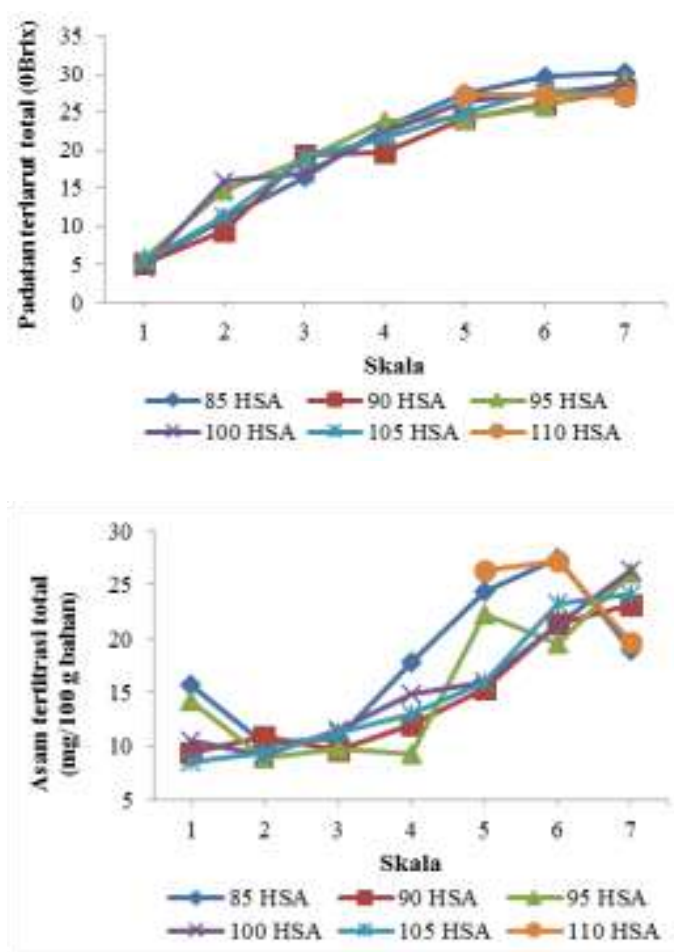

Gambar 3. Kualitas kimia pisang Raja Bulu pada beberapa umur petik 
Padatan terlarut total mengalami kenaikan seiring dengan bertambahnya umur simpan (Gambar 3) hal tersebut terjadi karena kandungan glukosa dan fruktosa yang meningkat selama proses pematangan. Kandungan asam buah rendah pada buah yang masih mentah dan meningkat selama proses pematangan sama seperti pada percobaan Sugistiawati (2013) yang mengalami kenaikan seiring dengan lamanya umur simpan. Menurut Santoso dan Purwoko (1995) kandungan asam organik pisang yang sangat tinggi diperoleh pada stadia matang penuh.

\section{KESIMPULAN}

Umur petik terbaik pisang Raja Bulu dicapai pada 85 HSA dengan umur simpan terlama (11 hari) serta satuan panas sebesar $1305.5^{\circ} \mathrm{C}$ hari. Buah pisang yang dipetik tua lebih cepat mencapai kematangan pascapanen dibandingkan dengan buah pisang yang dipetik muda. Pisang yang dipetik muda memiliki laju respirasi yang rendah dibandingkan dengan buah pisang yang dipetik tua. Umur petik tidak mempengaruhi mutu fisik dan kimia buah pisang pada tingkat kematangan pascapanen yang sama.

\section{DAFTAR PUSTAKA}

Arista, M. 2014. Penggunaan kalium permanganat sebagai oksidan etilen untuk memperpanjang daya simpan pisang Raja Bulu. Skripsi. Institut Pertanian Bogor. Bogor.

[BPS] Badan Pusat Statistik. 2013. Produktivitas pisang Indonesia. http://www.bps. go.id. [28 Oktober 2013].

Cahyono, B. 2009. Pisang Usaha Tani dan Penanganan Pascapanen. Kanisius. Yogyakarta.

Ferdaus, F., M.A. Wijayanti, E.S. Retnoningtyas, W. Irawati. 2008. Pengaruh pH konsentrasi substrat penambahan kalsium karbonat dan waktu fermentasi terhadap perolehan asam laktat dari kulit pisang. Widya Teknik. 7(1): 1-14.
Hanum, F., I.M.D. Kaban, M.A. Tarigan. 2012. Ekstraksi Pektin dari Kulit Buah Pisang Raja (Musa sapientum). Jurnal Teknik Kimia USU, Vol.1, No. 2. USU. Medan.

Jannah, U. 2008. Pengaruh bahan penyeram larutan kalium permanganat terhadap umur simpan pisang Raja Bulu. Skripsi. Institut Pertanian Bogor. Bogor.

Julianti, E., Ridwansyah, E. Yusraini, I Suhaidi. 2013. Pengaruh penyimpanan dengan atmosfer terkendali terhadap mutu buah rambutan 'Binjai'. J. Hort. Indonesia. 4(2): 63-69.

Kuntarsih, S. 2012. Pedoman Penanganan Pascapanen Pisang. Direktorat Budidaya dan Pascapanen Buah Kementerian Pertanian. Jakarta.

Mulyana, E. 2011. Studi pembungkus bahan oksidator etilen dalam penyimpanan pascapanen pisang Raja Bulu (Musa sp. AAB Group). Skripsi. Institut Pertanian Bogor. Bogor.

Pantastico, E.B. 1986. Fisiologi Pascapanen, Penanganan, dan Pemanfaatan Buahbuahan dan Sayur-sayuran Tropika dan Sub Tropika. Kamariyani, penerjemah. Gajah Mada University Pr. Terjemahan dari: Postharvest Physiology, Handling, and Utilization of Tropical and Sub Tropical Fruits and Vegetables. Yogyakarta.

Paramita, O. 2010. Pengaruh memar terhadap perubahan pola respirasi, produksi etilen dan jaringan buah mangga (Mangifera indica $\mathrm{L}$ ) var Gedong Gincu pada berbagai suhu penyimpanan. J. Kompetensi Teknik. 2(1): 29-37.

Phan, C.T., E.B. Pantastico, K. Ogata, K. Chachin. 1986. Respirasi dan Puncak Respirasi. Di dalam: E.B. Pantastico, editor. Fisiologi Pascapanen, Penanganan, dan Pemanfaatan Buah-buahan dan Sayur-sayuran Tropika dan Sub Tropika. Kamariyani, penerjemah. Gajah Mada University Pr. Terjemahan dari: Postharvest Physiology, Handling, and 
Utilization of Tropical and Sub Tropical Fruits and Vegetables. Yogyakarta.

[PKHT] Pusat Kajian Hortikultura Tropika. 2014. Nilai ekspor pisang Indonesia. http://pkht.deptan.go.id/. [3 Juli 2014].

Santoso, B., B.S. Purwoko. 1995. Fisiologi dan Teknologi Pascapanen Tanaman Hortikultura Indonesia. Indonesia Australia Eastern Universities Project.

Sugistiawati. 2012. Studi penggunaan oksidator etilen dalam penyimpanan pascapanen pisang Raja Bulu (Musa sp. AAB Group). Skripsi. Institut Pertanian Bogor. Bogor.

Sumantra, I.K., P. Suyasdi, A. Sumeru. 2014. Heat unit, phenology and fruit quality of salak (Salacca zalacca var. amboinensis) cv. Gula Pasir at different elevation in Tabanan Regency - Bali. Agriculture, Forestry and Fisheries. 3(2): 102-107. doi:10.11648/j.aff.20140302.18.

Suryana, A. 2006. Peran Teknologi Pascapanen dan Sistem Keamanan Pangan dalam Meningkatkan Nilai Tambah Hasil Pertanian. Balai Besar Penelitian dan Pengembangan Pasca Panen Pertanian. Jakarta.

Sutowijoyo, D. 2013. Kriteria kematangan pascapanen pisang Raja Bulu dan pisang Kepok. Skripsi. Institut Pertanian Bogor. Bogor. 